\title{
Evaluation of producer inflation, subsidies and profitability of vegetables and grains in Sinaloa, 2018-2019
}

\author{
Borbón-Morales, Carlos G. ${ }^{1^{*}} ;$ Martínez-Téllez, Miguel A. ${ }^{1} ;$ Rueda-Puente, Edgar ${ }^{2^{*}}$
}

\begin{abstract}
${ }^{1}$ Centro de Investigación en Alimentación y Desarrollo AC, Carretera Gustavo Enrique Astiazarán Rosas, No. 46, Hermosillo, Sonora, México. ²Universidad de Sonora, Carretera a Bahía Kino Km. 21, Hermosillo, Sonora, México.
\end{abstract}

*Corresponding author: erueda04@santana.uson.mx; cborbon@aciad.mx

\begin{abstract}
Objective: To evaluate producer inflation, equity in PROCAMPO subsidy distribution, as well as profitability of eight agricultural products in the state of Sinaloa, 2018-2019 cycle.
\end{abstract}

Design/Methodology/Approach: First, inflation is estimated in the value of agricultural production, using the agricultural producer price index (INPP) base 2019. Second, the inequality in the allocation of PROCAMPO is calculated with Lorenz curves. Third, the internal rate of return (IRR) is estimated for the eight products and compared with the 28-day yield of the treasury certificates (CETES).

Results: The current values generated show growth in cereals (corn, wheat), and vegetables (tomato, chili peppers), with downward inflationary gaps in the period 2000-2019. There is a concentration of the PROCAMPO allocation in producers with high income deciles. The IRR is high in vegetables, and low in corn and beans.

Study Limitations/Implications: This study does not specify the size of the productive unit and only the data is generalized. It does not address marketing channels and their destinations.

Findings/Conclusions: The producer is assuming the inflationary increase. Income transfers via PROCAMPO are inequitable. The IRR in corn and beans is sometimes less profitable than CETES.

\section{INTRODUCTION}

In MeXICO, agriculture and livestock productive units confront increasingly complex competitive products, variability of production costs, climate risks, impact from pests and diseases, among other aspects.

The agriculture and livestock sector, according to INEGI (2021), has had a participation in the GDP of 3\%. According to SIAP (2020), the average value between 2011 and 2019 was $\$ 895$ billion MXN, and the participations per subsector are: agriculture $55 \%$, livestock $42 \%$, and fishing 3\%. Although the three subsectors show a growing trend, agriculture shows the best performance with a growth higher than $8 \%$ (see Table 1). 
According to SIACON (2020), for the year 2019 the agricultural value reached $\$ 675,368$ million MXN, with nearly a third of this distributed among the states of Michoacán, Jalisco and Sinaloa. Taking as example the state of Sinaloa, one of these large agrifood producers, Figure 1 shows that slightly over one million hectares were sown, of which more than 500 thousand ha are for cereals that generate more than \$24 billion MXN; whereas vegetables, with 51 thousand hectares, produce more than $\$ 23$ billion MXN.

Table 2 shows that, in cereals, maize represents $56 \%$ of the surface planted and

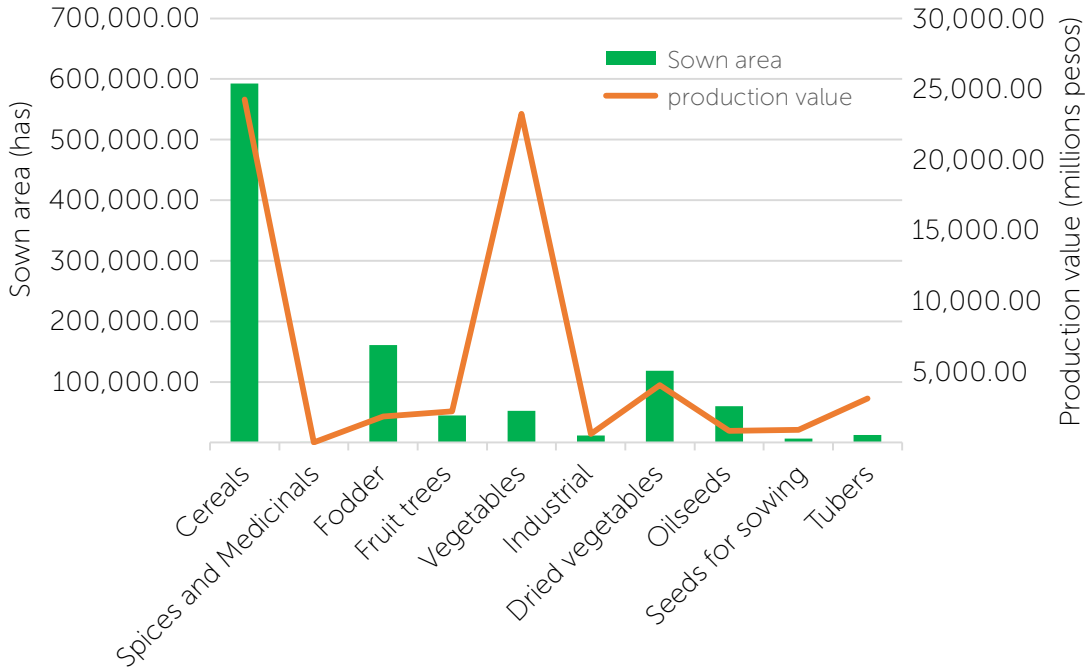

Figure 1. Sinaloa: planted area and production value, according to crop groups, 2019. Source: SIACON. https://www.gob.mx/siap/documentos/siacon-ng-161430
$38.5 \%$ of the production value. In vegetables,

tomato with slightly over $1 \%$ of the surface sown generates more than $12 \%$ of the state agriculture value. In turn, the accident rate, as approximate indicator of the risk level, shows with high indicators the following: tomato $15.2 \%$, maize and green chili pepper 13.5\%.

As complex systems, agrifood supply chains face multiple sources of uncertainty that can cause a significant imbalance between offer and demand in terms of varieties of products, amounts, qualities, client requirements, times and prices. All of these complicate their management (Alemany, et. al, 2021), which forces agricultural producers to confront various structural problems that cause increase in prices of agricultural and food products (Keskin, 2020). Within this scope, the PROCAMPO subsidy did not support technological

\begin{tabular}{|c|c|c|c|c|}
\hline Year & Agriculture & Livestock & Fishing & Sector total \\
\hline 2011 & 354,657 & 264,245 & 17,786 & 636,687 \\
\hline 2012 & 410,160 & 286,571 & 19,022 & 715,753 \\
\hline 2013 & 395,508 & 323,433 & 19,855 & 738,796 \\
\hline 2014 & 417,347 & 356,168 & 24,110 & 797,624 \\
\hline 2015 & 444,138 & 382,462 & 31,490 & 858,090 \\
\hline 2016 & 513,936 & 394,417 & 35,664 & 944,017 \\
\hline 2017 & 587,233 & 423,065 & 39,781 & $1,050,078$ \\
\hline 2018 & 641,026 & 451,566 & 41,728 & $1,134,321$ \\
\hline 2019 & 675,368 & 479,960 & 28,679 & $1,184,008$ \\
\hline Average value & 493,264 & 373,543 & 28,679 & 895,486 \\
\hline Percentage participation \% & $55 \%$ & $42 \%$ & $3 \%$ & $100 \%$ \\
\hline AAGR & $8.4 \%$ & $7.7 \%$ & $6.2 \%$ & \\
\hline \multicolumn{5}{|c|}{$\begin{array}{l}\text { Source: SIACON, SIAP, CONAPESCA, SAGARPA, 2020. https://www.gob.mx/siap/ } \\
\text { documentos/siacon-ng- } 161430 \\
\text { Notes: the value of the fishing sector for } 2019 \text { is estimated as an average for the period, since } \\
\text { SIACON does not report the data for that year. } \\
\text { AAGR=Annual Average Growth Rate }\end{array}$} \\
\hline
\end{tabular}

impetus, as Zarazúa et al. (2011) described. And, according to FAOSAGARPA (2015), its distribution was unequal, since in the states of northwestern Mexico, the support was concentrated in commercial production units

This study suggests three of the aspects that are crucial in the decisions made by producers: input prices (producer inflation); equity in the subsidy distribution; and financial profitability of the crop. The objective of this study is to evaluate the producer inflation, the equity in PROCAMPO distribution, as well as to compare the profitability of eight agricultural products with high accident rate with regard to a lowrisk financial instrument.

\section{MATERIALS AND METHODS}

In the first section, based on the current value SIACON (2020) and the price index of agricultural producer at constant value from 2019 INEGI (2021b), the producer inflation that the producer "absorbs" is estimated and which is not transferred to the consumer. According to Sidaoui et al. (2009), the producer prices have causality in the consumer 


\begin{tabular}{l|c|c|c|c}
$\begin{array}{c}\text { Table 2. Sinaloa: Production structure for selected products, 2019. } \\
\begin{array}{c}\text { Cultivated } \\
\text { product }\end{array}\end{array}$ & Sown area & $\begin{array}{c}\text { Harvested } \\
\text { area }\end{array}$ & $\begin{array}{c}\text { Damaged } \\
\text { surface }\end{array}$ & $\begin{array}{c}\text { Production } \\
\text { value }\end{array}$ \\
\hline Green chile & 0.49 & 0.42 & 13.50 & 3.55 \\
\hline Beans & 6.42 & 6.49 & 7.12 & 4.46 \\
\hline Chickpea & 4.76 & 4.84 & 0.00 & 2.21 \\
\hline Corn & 52.64 & 53.43 & 13.57 & 38.53 \\
\hline Potatoe & 1.15 & 1.17 & 0.00 & 5.09 \\
\hline Sorghum & 8.83 & 8.97 & 0.00 & 1.73 \\
\hline Tomatoes & 1.16 & 1.09 & 15.22 & 12.18 \\
\hline Wheat & 3.37 & 3.43 & 0.00 & 1.23 \\
\hline Total Sinaloa & 100 & 100 & 100 & 100 \\
\hline
\end{tabular}

Source: Own elaboration based on: SIACON 2020.

prices. In this sense, the percentage breach between the current value and the deflated value approximates as proxy indicator of inflation that the agricultural producer assumes without this increasing the consumer prices. Next, two equations on which this percentage is based are presented.

$$
\begin{aligned}
& V A C=\left(\frac{V A}{\text { innpa }}\right) * 100 \\
& D=(V A C-V A) / V A
\end{aligned}
$$

Where: $V A C=$ agricultural value at constant prices from $2019=100$; Innpa = national price index to the agricultural producer; VA=agricultural value at current prices; $D=$ percentage variation of the difference between current agricultural and constant value.

In the second section, based on the National Survey of Household Income Expense (Encuesta Nacional Ingreso Gasto de los Hogares, ENIGH), 2016 and 2018, through the SPSS version 14 software. The level of equity in the distribution of PROCAMPO subsidies.

The level of dispersion or concentration in the distribution of the subsidy is exhibited through the representation of Lorenz curves, according to the levels of income of the producer who receives them, as expressed in Figure 2, which connects the proportion of the producer's income with the proportion of subsidy accumulated. In this representation, the straight line of $45^{\circ}$ reflects an equal relation between the subsidy granted and the producer's income. A curve above implies progressive concentration, where those of low income participate more in the subsidy. For a regressive curve, the subsidies are concentrated in higher income deciles.

In the third part, based on the data from the Agro-costs portal by FIRA (2021), the production costs, yield, probable price, utility, and equilibrium points were obtained, for crops selected in the 2018-2019 cycle. Then, according to Mete (2014) and Molina, P.O. (2017), the IRT from each crop selected were estimated, and compared with the yields from a low-risk instrument, such as CETES at 29 days from BANXICO (2020). Where:

$$
\begin{gathered}
I P=Y^{\star} P \\
C U=C T / Y \\
T I R=I P / C U
\end{gathered}
$$

Where: $I P=$ probable income; $Y=y$ ield per ha; $P=$ price; $C U=$ unitary cost per ha by $t ; I R R=$ internal rate of return.

\section{RESULTS AND DISCUSSION}

\section{Sinaloa: Product Inflation}

The producer price is explained as the price fixed by him on the first instance of product purchasing. If the producer price index is applied to current agricultural

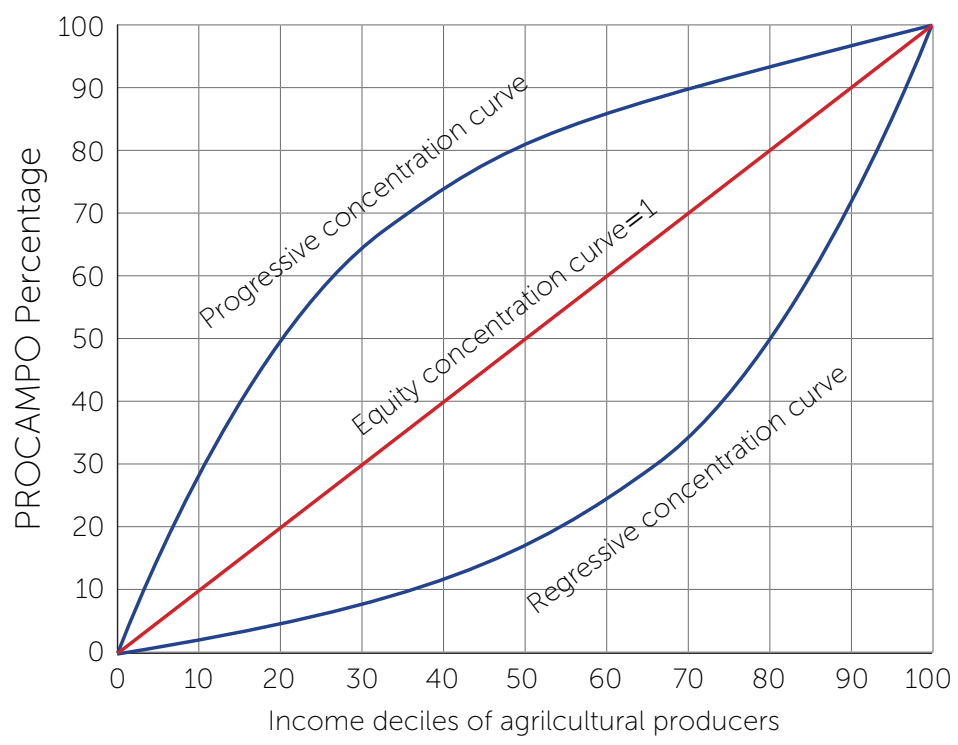

Figure 2. Lorenz curves, equity concentrations, progressive and regressive Source: Own elaboration based on: (Morales-Novelo et al., 2018, p. 5). 
value, a deflated series is obtained, where the current prices are transferred into constant prices 2019=100. Estimation of $D$ from equation 2 allows estimating the percentage variation of the difference between the current agricultural value and the constant value. Figure 3 expresses that in year 2000 it was $206 \%$, the highest of the period. Since that year and until 2017, this difference decreases consistently until reaching $0 \%$ in 2019. This gives evidence of how inflation has decreased in the agricultural sector in Sinaloa. Likewise, that the producers absorb inflation coming from the increase in prices of its inputs without transferring it to the consumers.

\section{Sinaloa: The Subsidy Effect}

According to Sadoulet (Sadoulet et al., 2001), as a consequence of the approval of NAFTA in 1994, a compensation program to transfer compensatory income to producers of basic crops was introduced, known as PROCAMPO.

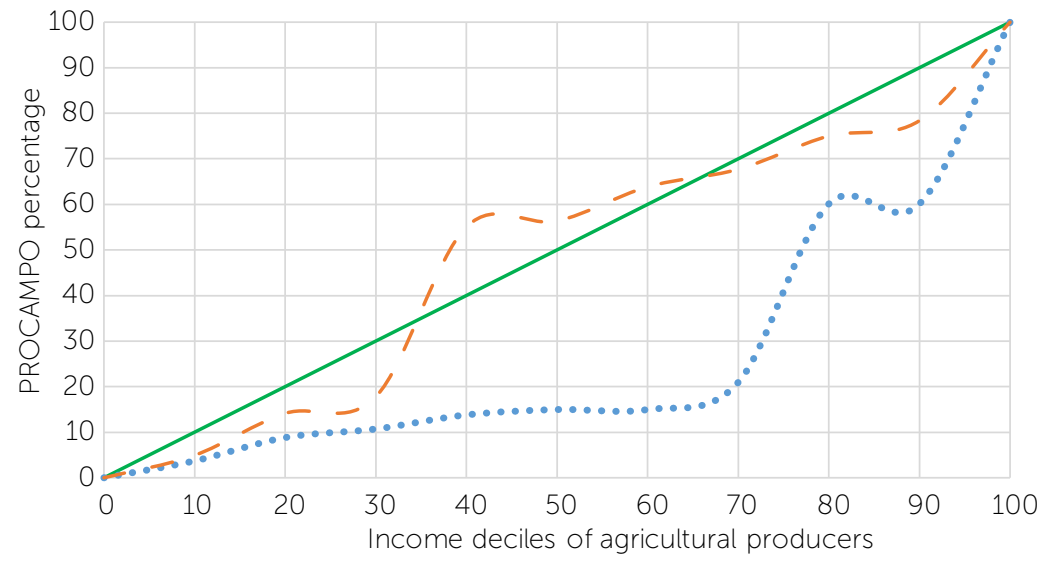

— PROCAMPO equity distribution ..... Lorenz curve of Sinaloa 2016 - - Lorenz curve of Sinaloa 2018

Figure 4. Sinaloa: Equity and inequality in the distribution of resources from procampo 2016 and 2018

Source: Own elaboration based on ENIGH 2016 and 2018
The effects of this compensatory measure, according to García et al. (2011), have stimulated the production of some products such as maize. In 2013, the program was restructured and since its implementation and up until 2018, it gradually reduced its coverage. From 1994 to 2018, on average \$11.45 billion MXN were assigned to it annually. For the case of the year 2018, the subsidy was concentrated in states such as: Chiapas, Zacatecas, Oaxaca, among others. For that same year, the state of Sinaloa received $4.3 \%$ of participations nationally, based on CEDRSSA with data from Noriega and Hidalgo (2019), FAO (2019) and SIAP (2019).

For the year 2016, Figure 4 shows that the subsidy is regressive, since the producers from high deciles ( 8,9 and 10) obtain between $60 \%$ and $90 \%$ of the subsidy. Meanwhile, the producers from low-income deciles (1,2 and 3), obtain less than $15 \%$ of resources. In turn, for 2018, a progressive effect is observed in deciles 4, 5 and 6 (medium producers). However, the deciles 8,9 and 10 continue to accumulate more than $75 \%$ and deciles 1 to 3 less than 15\% of the PROCAMPO resources.

\section{Agricultural Production Costs in Sinaloa.}

Referring to the production costs, in this section the production indicators of the 20182019 agricultural cycle in Sinaloa: production, value, yield, probable income price, total cost, net utility, unitary cost, point of equilibrium, and internal rate of return (IRR). Table 3 shows that regarding the production in tons, the crop that generates most production is maize with more than five billion tons, while that of lowest production is bean with 173,992 t. According to the value generated, maize shows $\$ 22,431,170$ MXN and wheat $\$ 1,103,360$ MXN. For the yield, 


\begin{tabular}{|c|c|c|c|c|c|c|c|c|}
\hline Concepts & Corn & Beans & Wheat & Sorghum & Chickpea & Tomatoes & Potatoe & $\begin{array}{c}\text { Jalapeno } \\
\text { pepper }\end{array}$ \\
\hline Production in $\mathrm{t}$ & $5,818,056$ & 173,992 & 241,522 & 325,873 & 193,078 & $1,088,252$ & 375,821 & 234,813 \\
\hline Value (in Mexican pesos) & $22,431,170$ & $2,534,612$ & $1,103,360$ & $1,121,143$ & $3,357,446$ & $7,024,020$ & $2,462,575$ & $1,405,789$ \\
\hline Yield (t/ha) & 11 & 2 & 5 & 8 & 2 & 130 & 30 & 50 \\
\hline Likely price $(\$ / t)$ & 3,960 & 16,000 & 5,010 & 3,564 & 16,000 & 5,500 & 7,000 & 7,000 \\
\hline Probable income (\$/ha)..(A) & 43,560 & 28,800 & 25,050 & 28,512 & 32,000 & 715,000 & 210,000 & 350,000 \\
\hline Total cost (in Mexican pesos) & 35,211 & 27,094 & 23,871 & 22,378 & 25,648 & 473,692 & 187,833 & 258,424 \\
\hline Net profit (pesos/ha) & 8,349 & 1,706 & 1,179 & 6,134 & 6,352 & 241,308 & 22,167 & 91,576 \\
\hline Unit cost (pesos/t/ha)...(B) & 3,201 & 15,052 & 4,774 & 2,797 & 12,824 & 3,644 & 6,261 & 5,168 \\
\hline Balance point (t/ha) & 8.89 & 1.69 & 4.76 & 6.28 & 1.6 & 86.13 & 26.83 & 36.92 \\
\hline Internal rate of return (A/B) & 1.24 & 1.06 & 1.05 & 1.27 & 1.25 & 1.51 & 1.12 & 1.35 \\
\hline
\end{tabular}

Source: AGROCOSTOS FIRA. 2018-2019.

they take it as an indicator of the technology used in the productive process. Tomato, which leads the figure with $130 \mathrm{t} / \mathrm{ha}$, while both chickpeas and bean only produces $2 \mathrm{t} / \mathrm{ha}$, respectively. Regarding the production costs, tomato is the one that shows highest cost with $\$ 473,692 /$ ha and the crop with lowest cost is sorghum with $\$ 22,378 /$ ha. If they compare utilities, tomato stands out with more than $\$ 241,000 / \mathrm{ha}$, and wheat has the lowest utility with \$1,179/ha.

Although these indicators can be a valid parameter for the producer to choose his best option, extra-economic aspects intervene such as: productive tradition, climate, contracts, among others. Next, two parameters are analyzed that are revealing about financial profitability, such as the business criterion. As Table 3 shows, the analysis of IRR as the financial indicator par excellence, that is, is the percentage of gain or loss that an investment will have, where IRR higher than one means investment where no losses are generated. In this case, following the analysis of the products mentioned above.

The IRR for each crop are the following: maize 1.24, bean 1.06, wheat 1.05, sorghum 1.27, chickpea 1.25, tomato 1.51, potato 1.12, and jalapeño chili pepper 1.35. Examined this way, all crops present favorable profitability, that is IRR $>1$. When comparing the financial yield as such from crop sowing, with the yield of CETES (treasury certificates at 28 days). That is, suggesting a comparative scenario, on which would be the best yield for an investor: CETES or sowing. In this case, according to Figure 5, bean and wheat show lower yields than CETES: bean IRR 1\%<CETES; wheat IRR $2 \%<$ CETES.

\section{CONCLUSIONS}

There is a tendency to decrease the transfer of prices from the producer to the consumer; that is, the producer has taken on the increase of prices from its inputs without transferring them to the consumer. The distribution of PROCAMPO subsidies is concentrated in the producers with deciles of higher income, but in the intermediate deciles it has been progressive. However, all the producers selected show a positive IRR, higher than one. When compared to the yield rate of CETES, as reference of a low-risk instrument in the market, wheat and bean exhibit lower yield rates. In sum, agriculture in Sinaloa transits as a productive activity where producers

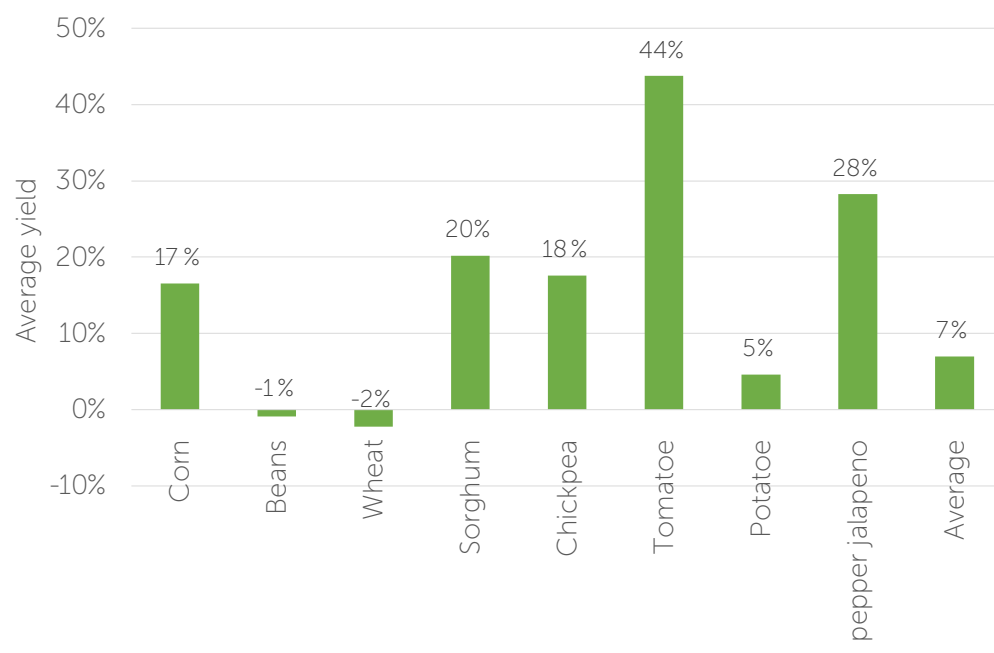

Figure 5. Financial Performance of the crop VS CETES at 28 days average 2018 Source: Own elaboration based on SIACON and BANXICO

https://www.banxico.org.mx/tipcamb/llenarTasasInteresAction.do?idioma=sp 
do not transfer their inflationary impacts; there is still concentration of the subsidies in high-income producers, and in traditional producers such as wheat and bean, sometimes more risks are taken than if they invested on low-risk instruments.

\section{REFERENCES}

Alemany, M. M. E., Esteso, A., Ortiz, A., Hernández, J. E., Fernández, A., Garrido, A., lannacone, R. (2021). A conceptual framework for crop-based agri-food supply chain characterization under uncertainty doi:10.1007/978-3-030-51047-3_2 Retrieved from www.scopus.com

BANXICO. (2020, 1 marzo). Tasas de interés. https://www.banxico.org $\mathrm{mx} /$ tipcamb/llenarTasas/nteresAction.do?idioma $=\mathrm{sp}$

CEDRSSA (2019), Centro de Estudios para el Desarrollo Rural Sustentable y la soberanía alimentaria. Los apoyos directos a la producción de granos básicos, del PROCAMPO a la producción para el bienestar. Palacio Legislativo de San Lázaro, Cd. México, marzo 2019

FAO-SAGARPA. (2015, 2 noviembre). Evaluación Nacional de Resultados 2013 Componente PROCAMPO. https://www. agricultura.gob.mx/sites/default/files/sagarpa/docume nt/2018/11/14/1531/14112018-evaluacion-nacional-deresultados-procampo.pdf

FIRA. (2021, 27 enero). Agrocostos. https://www.fira.gob.mx/Nd/ Agrocostos.jsp. https://www.fira.gob.mx/InfEspDtoXML/ TemasUsuario.jsp

García-Salazar, José Alberto, Skaggs, Rhonda K., y Crawford, Terry L. (2011). Evaluación de los efectos del Programa de Apoyos Directos al Campo (Procampo) en el mercado de maíz en México, 2005-2007. Economía, sociedad y territorio, 11(36), 487-512

INEGI (2012), Documento metodológico del INPP Cambio de base Junio 2012 = 100 Dirección General Adjunta de Índices de Precios Código: MP-05 Fecha de emisión: 22 de agosto.2012 Estado de revisión: 0 Fecha de próxima revisión: 15 julio 2013.
INEGI. (2021a, 25 febrero). Producto Interno Bruto Trimestral, cifras desestacionalizadas. https://www.inegi.org.mx/temas/pib/

INEGI. (2021b, 9 marzo). Indice Nacional de Precios Productor (INPP). Base julio 2019. https://www.inegi.org.mx/programas/ inpp/2019/

Keskin, G. (2020). Food inflation in turkey and the vicious cycle in agriculture: Structural problems. Fresenius Environmental Bulletin, 29(12), 11102-11110. Retrieved from www.scopus.com

Mete M. R. (2014). Valor actual neto y tasa de retorno: su utilidad como herramientas para el análisis y evaluación de proyectos de inversión, FIDES ET RATIO 7: (67-85)

Molina, P. O. (2017). Rentabilidad de la producción agrícola desde la perspectiva de los costos reales. Visión Gerencial, 16, 2, pp $217-232$

Morales-Novelo, J., Rodríguez-Tapia, L., \& Revollo-Fernández, D. (2018). Inequality in Access to Drinking Water and Subsidies between Low and High Income Households in Mexico City. Water, 10(8), 1023. https://doi.org/10.3390/w10081023.

Sadoulet E., De Janvry A, Davis Benjamín (2001). Cash transfer programs with income multipliers: PROCAMPO in Mexico. World Development 29, 6, pp 1043-1056.

SIACON (2020), Sistema de Información Agroalimentaria de Consulta. Del Servicio de Información Agroalimentaria y Pesquera. Consultado el 10 de abril del 2020 en: https://www.gob.mx/ siap/documentos/siacon-ng-161430

Sidaoui J., C. Capistrán, D. Chiquiar y M. Ramos-Francia (2009). Una nota acerca del contenido predictivo del INPP respecto a la inflación del INPC: el caso de México. Documento de Investigación 2009-14, Banco de México: 1-19.

Zarazúa-Escobar, José Alberto, Almaguer-Vargas, Gustavo, \& Ocampo-Ledesma, Jorge Gustavo. (2011). El programa de apoyos directos al campo (PROCAMPO) y su impacto sobre la gestión del conocimiento productivo y comercial de la agricultura del Estado de México. Agricultura, sociedad y desarrollo, 8(1), 89-105. http://www.scielo.org.mx/scielo. php? script $=$ sci_arttext\&pid $=$ S1870 $-54722011000100005 \&$ Ing =es\&tlng =es. 